\title{
A Critical Analysis of the Strategic Sector Privatization in Albania
}

\author{
Endri Papajorgji \\ PhD (Uni Graz) Mag. Iur (Uni Graz) \\ Karl Franzens Universität Graz, Universiteti Luarasi \\ endripapajorgji@hotmail.com
}

Doi:10.5901/ajis.2014.v3n4p319

\begin{abstract}
The privatization of the strategic sector has been the core of the privatization process in Albania. This strategy started in 1998 for the first time and is still in force for the remaining enterprises of the strategic sector. The changes of political and economic system in the early 90's in Albania required a broader reform of the entire legal system by creating a functioning market based in the rules of free market and competition and the privatization of state enterprises. The economic system of planned economy, which was established in Albania with the centralized control of economy through five-year plans for 45 years and state ownership (private property was abolished in Albania since the Constitution of 1976) as well as the binding of the enterprise to the priorities of the PPSH or to the fulfillment of the plan, led to the reduction of economic output, the rationing of consumer goods and, ultimately, after the political change to the transformation into a market economy (Åslund, 2013). Privatization and especially the strategic sector privatization was one of the main pillars of free market economy in Albania. My central contention in this paper is to analyse the strategic sector privatization in the perspective of EU standards. In this point of view this process in Albania can only be meaningfully thought through, and I suggest implemented, within the context of the European market (Gärtner 1996), but on the other hand the way this transformation had to be mastered was not clearly defined.
\end{abstract}

Keywords: Strategic sector, Privatization, Economy, Law, Albania.

\section{Introduction}

This article analyzes the strategic sector privatization in Albania that was implemented in 1998, but the non strategic sector privatization process started in 1990 with the privatization of small shops, small units of commercial services, vehicles, fishing boats, agriculture equipment, etc (Dervishi, 1993). During 1991-1997, Albania implemented all kind of privatization methods, starting with direct sales, auction, distribution of vouchers, action sales. During this period the Albanian authorities were totally overwhelmed with the privatization process, due to the fact that there were no prescribed legal structures and frameworks, that were able to ensure a proper procedure. Neither existed sufficient legal criterias or a commited administration. To evaluate the process in organizational terms, the adequate word would be "confusion".

The analysis of the strategic sector privatization that started in 1998 will show if this process had the same negative results as that of non-strategic sectors. The new government that came in power in july 1997, finally decided on a long-term privatization strategy to make the privatization process more effective. The new regulatory framework for the privatisation of the remaining 470 SMEs was approved in March 1998. According to EBRD (1998), the ownership rights of non-viable companies were to be transferred to local authorities and the others transformed into joint-stock companies and then sold in auctions. At the same time, it also approved the strategy for the privatisation of the strategic sectors of the economy.

With the entry into force of the new regulatory framework in 1998, the right of first choice of the workers was abolished and replaced by the tender sale process and auction as a single privatization process. The Tender-sale method was applied when the companies to be privatized were particularly significant or should be sold with conditions (Llaci, Sh., Mema, F. Pine, V., 2004). Law No. 8334 of $23.4 .1998^{1}$ prescribed the method of privatization for the strategic sectors. As of Art 3 of this law defined that public auction was the only privatization method used for the privatization of these enterprises. Ministry of Economy and Privatization included the privatization formula that defined the portion of shares of former owners and workers of the company, and handed over the documents to the privatization agency, which 
organized the auction process. From the earnings of the privatization process, the privatization agency should receive 5 $\%$ and the Ministry of Economics $20 \%$ of the retail value, while the rest should be paid to the state budget. ${ }^{2}$

The privatization process of state-owned enterprises was regulated with "Decision of CoM No. 230 of 04.04.1998". Ministry of Economy as the owner of state-owned capital chose an economic expert for the preparation of documentation. The appointment of economic experts were defined as the beginning of the privatization of the state capital of enterprises. Within 30 days of appointment of the experts, the privatization documents should be completed and handed over to the Privatization Agency, which organized the auction for the sale of shares. All complaints were supported by the Ministry of Economy and Privatization who assisted as a principal body as well as local authorities who monitored the company and the transformation into a joint stock company (Papajorgji, 2013).

\section{The Privatization Method of Strategic Enterpries}

With "Law No. 8306 of 14.3.1998 on the strategy of privatization of strategic"3 finally began the last and decisive period in the transformation process: the privatization of the remaining 470 SMEs (EBRD, 1998). As of Article 7 the privatization of the strategic sectors should be implemented with the participation of strategic investors who had to buy no less than $30 \%$ of the shares, while the privatization with vouchers should not exceed the value of $20 \%$. Enterprises operating in strategic sectors were natural monopolies and highly vertically integrated with most of them experiencing financial difficulties. The restructuring and privatisation of these sectors needed large investments which could be undertaken only by strategic investors (Cungu, A., Swinnen, F. M, 1997). In order to make these sectors more attractive, enterprises underwent some restructuring activities before privatisation. They were to be transformed into joint-stock companies and then some of them (especially the vertically integrated ones) were broken into smaller units.

The intention of the government, which was advised by international institutions such as the IMF and WB, was directed into attracting the foreign strategic investors who would bring new technologies, capital, corporate structures and know-how (Llaci, Sh., Mema, F. Pine, V., 2004). With Decision of CoM No. 408 of 31.8.1999 the tender sale method was established as the only method for the privatization of strategic enterprises. This process consisted of the open and restricted tender.

In the open tender all interested bidders were invited to offer, while the restricted tender included only those candidates who were allowed to present their offers and were invited directly the privatization agency. These procedures are in full compliance with the open and restricted procedure under European procurement law.

The documents for the privatization process were prepared by the state enterprise and submitted to the Ministry of Economy and Privatization, which passed them to the Privatization Agency. This organized the process and published the invitation for participation in the tender sale process three months in national newspapers. ${ }^{4}$ The publication should include the name of the object, the surveying data, the location, the activities and the balance sheet of the Company (Article 5). All invitations should be sent to the Commission for the evaluation of the bids, the representatives of the Privatization Agency, the Ministry of Economy and Privatization and its subordinate administrative organs (Article 4). The Commission should also publish the results of the first three candidates with a decision after the evaluation. Following the decision of the Commission, the privatization agency should sign a contract with the successful candidate. If this did not meet the contract terms, the runner up should sign the contract. With the signing of the contract ended the tender sale process.

\section{The Privatization Process of Strategic Enterprises}

The first of these strategic companies to be privatised was the only GSM (Global System for Mobile communication) operator in Albania, Albanian Mobile Company (AMC) (EBRD, 1998). This process began with the "Decision of the CoM No. 581 of 8.12.1999 on the criteria for the evaluation of tenders for the privatization of the AMC AG". After the tender sale process and the evaluation of the offers made by the Evaluation Commission, the decision of the Council of Ministers No. 255 was taken in 27.5.2000. This included the approval of the evaluation report for the privatization of AMC and the sales contract between the Ministry of Economy and Privatization and the Cosmote/Telenor companies. An 85\%

\footnotetext{
${ }^{2}$ Article 5 of Law No 8334 of 23.4.1998.

${ }^{3}$ Ligj Nr 8306 Për strategjinë e privatizimit të sektorëve me rëndësi të vecantë, datë 14.3.1998, FI Z 1998, Nr 8, 275.

${ }^{4}$ Article 3 of the Decision of the CoM No. 408 of 31.8.1999.
} 
stake of AMC was sold to a Greek-Norwegian consortium (Cosmote-Telenor) in July 2000, for US\$96 million (EBRD, 2000). After privatization, AMC reported an increase in company profits, in the number of subscribers as well as its geographical coverage (EBRD, 2000).

A year later, the decision of the Council of Ministers No. 433 of 4.8 .2000 opened the tender sale process for the purchase of the second license for the GSM telecommunications. With Decision No. 452 of 28.6.2001, this license was sold to Vodafone (UK) and Panafon (Greece) for U.S. \$ 38 million (EBRD, 2001).

The law on the privatisation of the fixed line telecommunication company, 'Albtelecom', was approved in May 2001, anticipating that $51-76 \%$ of the company will be sold to a strategic investor. The first tender for privatisation was announced in January 2002, but failed to attract investors' interest reflecting the unresolved financial and legal disputes of the company (EBRD, 2002). Finally, based on the "law No 9785 of 19.7.2007 on the ratification of the purchase agreement of shares of Albtelekom" 76 percent of the shares were sold for 120 million euro to a Turkish group (Turk Telekom and Calik Enerji telecommunications).

In the financial sector one of the two state banks, the National Commercial Bank, was privatised in June 2000. A $60 \%$ stake was sold to Kentbank of Turkey and the remaining 40\% to the International Finance Corporation (IFC) and EBRD (EBRD, 2000). The larger state-owned bank, the 'Saving Bank', was finally sold to the 'Raiffeissen Zentral Bank of Austria' in December 2003 - after three earlier attempts failed mainly due to the lack of investors' interest.62 Another company currently being considered for privatisation is the state-owned insurance company INSIG. The Government reached an agreement with the EBRD and IFC, in July 2003, according to which each of the two institutions would buy a $20 \%$ stake of the INSIG, with $51 \%$ of the company to be sold to a strategic investor within the next two years and the rest (9\%) will be offered to the public (EBRD, 2003). But even in 2014 INSIG is still in state hands.

The mining sector, also, has been under restructuring and privatisation after 1998. Most of the companies and mines operating in this sector have experienced a very difficult economic situation during transition. In order to develop this sector the government considered another form of privatisation by transferring to the investor only development and utilisation rights (as concessionaires). In May 2000 most of the chromium industry was given to an Italian company Darfo through a 30-year concession contract. Other parts of the chromium industry were leased for 20 years to a Turkish company. An American company (Metal Research Group) acquired a 30-year concession for the state-owned copper firm (Albbaker) in July 1999, but in 2000 it abandoned the concession (blaming it on the fall in the world copper price) and caused serious difficulties for the remaining copper mines (EBRD, 2000).

The international airport in Tirana was leased (through a concession agreement) to the German- American consortium "Airport Partners" for 20 years, while rail transport and the seaport sector are still in state hands. These companies were already transformed into joint stock companies and are waiting for privatization (EBRD, 2004).

The oil sector has undertaken deep restructuring before privatisation. First the state-owned company Albpetrol was transformed into a joint stock company called Albanian Petroleum Corporation (APC) and then three subsidiaries were created: SERVCOM for petroleum distribution, ARMO for processing and marketing and ALBPETROL for exploration and extraction. The privatization of ARMO was regulated by "Law No 9117 of 24.7.2003 on the determination of the privatization formula of ARMO". It provided for the privatization of not less than $51 \%$ of the shares of ARMO through an open international tender sale process. With "Law No. 9993 of 18.9.2008 on the ratification of the contract of sale of the shares of ARMO between the Ministry of Economy and Privatization and the buyers of the AMRA OIL and the Group Refinery Associates of Texas, Anika Enterprises Mercuria Energy Group, 85 percent of the shares were sold at a price of EUR 127.75 million (EBRD, 2008).

Efforts have been made to restructure the Albanian Power Corporation, $\mathrm{KESH}$, with the help of international institutions (EBRD and World Bank). KESH was divided according to the "Decision of the CoM No 797 of 4.12.2003" in KESH for Production and transmission and the OST for distribution of electricity. With Law No. 9889 of 20.3.2008 the open international tender sale process has been set for the sale of state-owned shares of the OST AG (Type 1), and in accordance with Article 3 not less than 51 percent and not more than 76 percent of the shares should be offered to strategic investors. With decision of the CoM No. 1430 of 29.10.2008, 76 percent of the shares of OST were sold for 102 million euros to the Czech company CEZ.

\section{Actual Situation of the Privatization Process}

In this section, will be presented the current situation of the strategic sector privatization process. It is also unclear whether and, if necessary what lessons the Albanian government has drawn from the (mis) developments of the nonstrategic privatization. 
It can be noted that the privatization process is well advanced. However, still remain a few sectors in which companies have not yet been transferred to private ownership. ${ }^{5}$ Financial problems are at the center of the current dispute between the Czech company CEZ and the Albanian state-owned KESH (EBRD, 2012). Meanwhile, a current dispute has developed. This meant that the Czech company has lost its license. ${ }^{6}$ On 16.5.2013 CEZ has therefore appealed to the International Court of Arbitration in London. ${ }^{7}$ The difficulties were caused by the fact that CEZ was on the one hand forced to buy expensive electricity and on the other hand it was prohibited by the Albanian regulatory authority to reallocate these additional costs to the Albanian consumers. This had the consequence that CEZ generated with each kilowatt a loss. In addition, in early 2012 the electricity prices increased in Albania and also the poor payment performance of the Albanian consumers were other factors for this dispute.

The privatization of oil industry also caused problems. In December 2011, the Albanian Parliament approved the sale of the state-owned oil producer Albpetrol with "Law No 10490 of 15.12.2011 on prescribing the formula of privatization of Albpetrol". 8 Article 3 of this law establishes a privatization formula, which provided that 100 percent of the shares of capital should be offered to strategic investors in the oil industry in an open international tender sale process.

With the "Decision of the CoM No. 634 of 10.03.2012 on the approval of the final report on the evaluation of tenders and announcement of the winner of the tender process for the privatization sale of the company Albpetrol"9 the company Vetro Energy PTE. Ltd. was declared the winner of this tender.

The government gave the Company Vetro Energy PTE Ltd a deadline of 30 days to pay $10 \%$ of the purchase price in the amount of 85 million euros. Although this deadline was extended after discussions with the government by two months, the company did not fulfill its obligations for the payment. It was argumented from the company Vetro Energy PTE Ltd that they erroneously assumed to acquire through this process all Albanian oil resources with a total area of 850 $\mathrm{m} 2$.

In fact, there is a presumption that this company whose bid was four times higher than that of the runner-up, was not able to fund the full acquisition of capital, and the arguments of the company Vetro Energy PTE Ltd were an excuse for the withdrawal from the contractual obligations. The new government that came into force in June 2013, still hasn $t$ decided for the formula and structure of privatization of Albpetrol.

The Government of Albania is trying to privatize since 2010 a total of 15 percent of the remaining state-owned shares of the company ARMO AG and 16.8 percent of the telecommunications company Albtelekom the largest fixed-line telecommunications company in Albania, through an international tender sale process (EBRD, 2012). The government is also trying after two failed attempts to privatize the state insurance company INSIG (EBRD, 2011).

Concession agreements are another form of privatization, that were often used since 2007, particularly in the energy sector. To take advantage of the immense water reserves, the Government of Albania has so far completed more than 50 concession contracts with domestic and foreign investors for the construction of small hydropower plants.

\section{Conclusions}

After this presentation and analysis of the strategic sector privatization, the following conclusions can be drawn:

After the political changes of the early 1990s, Albania was governed by anarchy more than other country from the socialist bloc. The strategic sector privatization that started in 1998 didn't fulfill the expectation of the Albanian governments and people. It shows only one thing, namely that the problems in the privatization of non-strategic sector were not corrected for strategic enterprises through the tender sale process. The deadlines for the privatization of these companies were not respected, the sales value of the shares was not respected, and the obligation to pay the annual salaries of unemployed workers as a result of restructuring was disregarded. Foreign investors didn't bring any new

\footnotetext{
${ }^{5}$ For more look at, http://www.balkans.com/print-news.php?uniquenumber=97196 (20.9.2013).

6 For more look at, http://wirtschaftsblatt.at/home/nachrichten/europa_cee/1335218/Stromstreit-in-Albanien_C EZ-ver liert-Lizenz/ (20.9.2013).

${ }^{7}$ For more look at, http://www.encharter.org/fileadmin/user_upload/InvestorState_Dispute s/CEZ_press_release.pdf (Stand 20.9.2013); look also, http://www.radio.cz/de/rubrik/tagesecho/teures-balkangeschaeft-energiekonzern-cez-in-albanien-ge scheitert (20.9.2013).

${ }^{8}$ Ligj Nr 10490 Për përcaktimin e formës dhe të strukturës së formulës së privatizimit të shoqërisë "Albpetrol" sh.a, datë 15.12.2011, FI Z 2011, Nr 166, 8409.

${ }^{9}$ Vendim i Këshillit të Ministrave Nr 634 Për miratimin e raportit përfundimtar të vlerësimit të ofertave dhe shpalljen e fituesit të tenderit për privatizimin e shoqërisë "Alpetrol" sh.a, datë 3.10.2012, FI. Z. 2012, Nr 133, 7625.
} 
technology, know how and employment. The purchase contracts contained no obligations for employment; Some purchase contracts didn't contain obligations relating to the investment, some did. This lays the question: Why was privatization not implemented through a uniform procedure?

The answer is clear: The reason for the divergent privatization process is corruption and direct interests of the government. There were and are in Albania also many concepts and ideas about the privatization of strategic enterprises. A bigger problem is the monopoly of privatized enterprises. To evaluate the process in organizational terms, the adequate word would be "confusion".

Finally, the restructuring of companies before privatization was not successful and wherever you go in the country, people tell you how tough life is. Average salaries are $€ 300$ in Albania. By contrast prices are high and increasing, especially for utilities and one of the consequences is privatization.

All in all: Privatization of strategic sector in Albania can serve as a negative example of how legal and economic transformation processes should not be implemented.

\section{References}

Asslund, S. (2013), How capitalism was built - The Transformation of Central and Eastern Europe, Russia, the Caucasus and Central Asia, p. 2.

Boric, T. (2013), Rechtsvergleichung. Graz.

Cungu, A., Swinnen, F. M. (1997), Albania's Radical Agrarian Reform, Economic Development and Cultural Change.

Dervishi, P. (1993), Privatization in Albania-1992, CEEPN, Privatization in Central \& Eastern.

EBRD (1998), Transition Report Albania, p. 114.

EBRD (2001), Transition Report Albania, p. 148.

EBRD (2008), Transition Report Albania, p. 119.

EBRD (2011), Transition Report Albania, p. 138.

EBRD (2012), Transition Report Albania, p. 127.

Gärtner, W. (1996), Die Eigentumsgarantien in den Verfassungen Polens, Ungarns, der Tschechischen und der Slowakischen Republik. Verfassungsrechtliche Grundlagen und Verfassungspraxis, Eigentum in Osteuropa. Peter Lang, Berlin, p. 219.

GTZ (1998) Raport mbi procesin e privatizimit.

Llaci, Sh., Mema, F., Pine, V. (2004), Pasojat sociale te privatizimit.

Papajorgji, E. (2013), Privatisierung von Unternehmen in Albanien und Mazedonien im Rechtsvergleich. Saarbrücken.

\section{Legislation}

Ligj Nr 8334 Për Privatizimin e shoqërive tregtare që veprojnë në sektorët jostrategjik (Law no. 8334 For privatization of non-strategic sectors commercial companies), datë 23.4.1998, Fl Z 1998, Nr 12, 437.

Ligj Nr 8306 Për strategjinë e privatizimit të sektorëve me rëndësi të vecantë (Law no. 8306 For the privatization strategy of strategic sectors), datë 14.3.1998, FI Z 1998, Nr 8, 275.

Ligj Nr 10490 Për përcaktimin e formës dhe të strukturës së formulës së privatizimit të shoqërisë "Albpetrol" sh.a (Law no. 10490 For defining the form and structure oft he privatization formula of Albpetrol), datë 15.12.2011, FI Z 2011, Nr 166, 8409.

Vendim i Këshillit të Ministrave Nr 634 Për miratimin e raportit përfundimtar të vlerësimit të ofertave dhe shpalljen e fituesit të tenderit për privatizimin e shoqërisë "Alpetrol" sh.a (Decision of CoM No 634 for the approval of the final report of evaluation of offers and the publication of the tender winner for the privatization of Albpetrol), datë 3.10.2012, Fl. Z. 2012, Nr 133, 7625.

\section{Websites}

http://www.balkans.com/print-news.php?uniquenumber=97196 (20.9.2013).

http://wirtschaftsblatt.at/home/nachrichten/europa_cee/1335218/Stromstreit-in-Albanien_C EZ-ver liert-Lizenzl (20.9.2013).

http://www.encharter.org/fileadmin/user_upload/InvestorState_Dispute s/CEZ_press_release.pdf (Stand 20.9.2013); look also, http://www.radio.cz/de/rubrik/tagesecho/teures-balkangeschaeft-energiekonzern-cez-in-albanien-ge scheitert ( 20.9.2013). 
